\title{
QUEEN'S
UNIVERSITY
BELFAST
}

\section{Peer effects in UK adolescent substance use: Never mind the classmates?}

McVicar, D., \& Polanski, A. (2014). Peer effects in UK adolescent substance use: Never mind the classmates? Oxford Bulletin of Economics and Statistics, 76(4), 589-604. https://doi.org/10.1111/obes.12030

Published in:

Oxford Bulletin of Economics and Statistics

\section{Document Version:}

Peer reviewed version

Queen's University Belfast - Research Portal:

Link to publication record in Queen's University Belfast Research Portal

\section{Publisher rights}

(c) 2013 The Department of Economics, University of Oxford and John Wiley \& Sons Ltd.

This is the accepted version of the following article: McVicar, D. and Polanski, A. (2014), Peer Effects in UK Adolescent Substance Use: Never Mind the Classmates?. Oxford Bulletin of Economics and Statistics, 76: 589-604. doi: 10.1111/obes.12030, which has been published in final form at http://onlinelibrary.wiley.com/doi/10.1111/obes.12030/abstract.

\section{General rights}

Copyright for the publications made accessible via the Queen's University Belfast Research Portal is retained by the author(s) and / or other copyright owners and it is a condition of accessing these publications that users recognise and abide by the legal requirements associated with these rights.

Take down policy

The Research Portal is Queen's institutional repository that provides access to Queen's research output. Every effort has been made to ensure that content in the Research Portal does not infringe any person's rights, or applicable UK laws. If you discover content in the Research Portal that you believe breaches copyright or violates any law, please contact openaccess@qub.ac.uk. 


\title{
Peer Effects in UK Adolescent Substance Use: Never Mind the Classmates?*
}

\author{
DUNCAN MCVICAR† and ARNOLD POLANSKI \\ †Melbourne Institute of Applied Economic and Social Research, University of Melbourne, Vic \\ 3010, Australia, (email: dmcvicar@unimelb.edu.au) \\ $\ddagger$ School of Economics, University of East Anglia, Norwich NR4 7TJ, United Kingdom, (email: \\ a.polanski@qub.ac.uk)
}

\begin{abstract}
This paper estimates peer influences on the alcohol, tobacco and cannabis use of UK adolescents. We present evidence of large, positive and statistically significant peer effects in all three behaviours when classmates are taken as the reference group. We also find large, positive and statistically significant associations between own substance use and friends' substance use. When both reference groups are considered simultaneously, the influence of classmates either disappears or is much reduced, whereas the association between own and friends' behaviours does not change. The suggestion is that classmate behaviour is primarily relevant only inasmuch as it proxies for friends' behaviour.
\end{abstract}

JEL: I12, Z13

Keywords: peer effects, reference groups, smoking, alcohol, cannabis, adolescents, friends

\footnotetext{
* Thanks to the ESPAD team for the data. The United Kingdom ESPAD study was conducted by Professor Martin Plant and Dr Patrick Miller of the University of the West of England, Bristol (UWE). It was mainly funded by the Wates Foundation and UWE. Additional support was provided by the Joseph Rowntree Foundation, the Oakdale Trust, Butcombe Brewery Ltd, Dr George Carey, the Jack Goldhill Charitable Trust, R\& J Lass Charities Ltd and the North British Distillery Company Ltd. Thanks also to seminar participants at Queen’s University Belfast, the Melbourne Institute of Applied Economic and Social Research, the Irish Economic Association Conference 2009, the European Meeting of the Econometric Society 2009, the European Association of Labour Economists Conference 2009 and the Australian Conference of Economists 2010 for useful comments on earlier drafts.
} 


\section{Introduction}

Peer effects (or social interactions effects) refer to externalities in which the actions or characteristics of a reference group affect an individual's behaviour. Such effects have been studied in a huge variety of social contexts - for recent reviews see Brock and Durlauf (2001), Soetevent (2006) and Ioannides (2008) - although the literature is yet to arrive at a firm consensus about their magnitude or even their existence. This is also true for the specific literature concerning peer effects in adolescent substance use, despite the conventional wisdom that they are a key factor influencing individual behaviour. Part of the explanation for this lies in the well-known difficulties associated with identifying peer effects as set out by Manski (1993). But lack of suitable data may have also played a role by focussing research efforts on less relevant reference groups. Most studies in the literature on peer effects in adolescent substance use are based on readily available school-based survey data, where the school, school grade or school class is treated as the reference group. For behaviours that mostly take place outside of school hours such as cannabis use, however, it is questionable whether these are the most relevant reference groups. ${ }^{1}$

In this paper we exploit UK data on substance use among classmates and among friends to provide new estimates of peer effects in the UK for both reference groups, along the lines of Gaviria and Raphael (2001) and Kawaguchi (2004) respectively. Our main contribution, however, is to show that the influence of classmates is much diminished, and may even disappear altogether, where both reference groups (friends and classmates) are included

\footnotetext{
${ }^{1}$ Questions about which peers have the most influence for which behaviours, although often overlooked in the empirical economics literature on peer effects, are not new to the social sciences (see, for example, Granovetter (1973) and Oetting and Beauvais (1987)). This is also an issue in the more recent networks literature, with some models allowing for 'neighbour' effects on behaviour only from direct neighbours (e.g. Calvo-Armengol et al., 2009), and others allowing additional effects from more distant neighbours (e.g. Jackson and Wolinsky, 1996).
} 
simultaneously in a reduced-form regression model for own behaviour. In our data, friends are the more relevant reference group for peer effects in adolescent substance use, and classmates that are not friends may have little or no influence.

Evidence regarding which peers influence which behaviours is critical to understanding adolescent substance use. ${ }^{2}$ It can help guide future studies of adolescent substance use, and studies of peer effects in particular, towards arguably more appropriate models and data sources. It can also help us interpret the range of existing estimates in the adolescent substance use peer effects literature. For example, estimates of zero peer effects between grade-mates (e.g. Clark and Lohéac, 2007) may be perfectly consistent with large peer effects between friends (e.g. Norton et al., 2003). And studies that estimate large and statistically significant peer effects between classmates may be mostly picking up peer effects between friends, some of whom happen to be in the same school class. Such evidence can also help to target policy interventions aiming to exploit social multipliers to reduce adolescent substance use.

The remainder of the paper is set out as follows. Section 2 briefly summarises the existing empirical literature on peer effects in adolescent substance use. Section 3 describes the data. Section 4 sets out our estimation approach. Section 5 presents and discusses our estimates of peer effects with both the school class and friends treated as reference groups. Section 6 concludes.

\section{Existing Literature}

Table 1 summarises the existing economics literature estimating peer effects in adolescent substance use. These studies have used a variety of data, a variety of econometric methods, and

\footnotetext{
${ }^{2}$ And understanding adolescent substance use is critical because tobacco smoking, for example, is the largest single cause of avoidable death in the EU, with most smokers beginning to smoke in adolescence, and with adolescent smoking a very strong predictor of later smoking (McVicar, 2011).
} 
have specified a variety of different reference groups. But most common are studies using school-based surveys and specifying schoolmates, grade-mates or classmates as the reference group. They have tended to focus on the prevalence of one or more behaviours in the reference group and how it impacts on the decision of an individual to participate in the behaviour(s), usually measured as whether the individual has smoked at least one cigarette, used alcohol or used cannabis on at least one occasion in the last 30 days. Most provide simple probit or OLS estimates where peer behaviour is treated as if it were exogenous, together with IV and/or school fixed effects estimates that try to address the various identification issues set out by Manski (1993). Most conclude that peer effects are positive, statistically significant, and large in magnitude, regardless of the methods adopted and the particular reference group or behaviour studied. ${ }^{3}$ A simple unweighted average of the estimates reported in Table 1 suggests that a one percentage point increase in reference group substance use participation leads to a one quarter percentage point increase in probability of own use. Estimates of peer effects in tobacco smoking tend to be larger than those for alcohol use, which in turn are larger than those for cannabis use. There is, however, no clear pattern in terms of the magnitude of estimated peer effects across the different reference groups.

Of these studies, only Clark and Lohéac (2007) provide estimates of peer effects for two different reference groups - friends in school and the school grade - using the same data set and same methods. ${ }^{4}$ They estimate positive and statistically significant peer effects from friends for

\footnotetext{
${ }^{3}$ The main exceptions are estimates based on alternative identification strategies suggesting only small or even zero peer effects in adolescent substance use (e.g. the sibling fixed effects estimates of Kawaguchi (2004), the 'removal of user friend' estimates of Eisenberg (2004), and the school fixed effects/lagged peer behaviour estimates of Clark and Lohéac (2007)).

${ }^{4}$ Eisenberg (2004) also provides estimates of peer effects in adolescent substance for two different reference groups - friends and the school - but using rather different methods in each case which makes the resulting estimates difficult to compare. Nevertheless the pattern is similar to that suggested by Clark and Lohéac (2007): friends appear to be a more consistently relevant reference group for these behaviours than do schoolmates.
} 
all behaviours. For grade-mates, however, their estimated peer effects are close to zero in magnitude and statistically insignificant for both tobacco and cannabis use. Clark and Lohéac (2007) put this down to a combination of larger peer effects for friends than for grade-mates and additional positive bias due to endogenous selection of friends. To the extent that these results are picking up the former, they provide a good illustration of the dangers of generalising inferences about peer effects from one reference group to another. Even where Clark and Lohéac (2007) estimate positive and significant peer effects between grade-mates, however, because models are estimated separately for each reference group we cannot rule out the possibility that grade-mate substance use is merely proxying for friends' substance use. If we want to test whether friends and grade-mates are both (independently) relevant reference groups then we need to estimate a model where the substance use of both reference groups is included simultaneously. ${ }^{5}$

\section{The ESPAD Data}

The data used here are drawn from the UK part of the 2003 sweep of the European Schools Survey Project on Alcohol and Other Drugs (ESPAD) survey which randomly selected a representative sample of schools across the country from which single classes of pupils in their final year of compulsory education, i.e. aged 15 or 16 years, were themselves randomly selected. All (present) members of each class were given the ESPAD questionnaire to complete, anonymously, during school hours, and under exam conditions. The completed forms were then sealed in envelopes, collected by staff, and posted to the survey team. After cleaning a small

\footnotetext{
${ }^{5}$ If there are no peer effects from grade-mates that are not also friends, then we would expect a zero coefficient on the grade-mates behaviour variable when friends' behaviour is included in the model, or at least no increase in the model's explanatory power when grade-mate behaviour is added alongside friends' behaviour.
} 
number of spoiled forms, the resulting database contains self-reported information on over 2000 individuals across 77 schools. $^{6}$

The questionnaires ask a number of questions relating to own smoking, drinking and drug taking behaviour. We focus on the following questions:

- How frequently have you smoked cigarettes during the last 30 days?

- On how many occasions in the last 30 days (if any) have you had any of the following to drink (beer, wine, spirits, also include sprits mixed with soft drinks)?

- On how many occasions (if any) have you used cannabis (marijuana, dope, grass, pot) or hashish (hash or hash oil) during the last 30 days?

Each of these questions has a seven-point scale for responses, ranging from 'none/not at all' through to 'more than 20 cigarettes/40 or more drinks/40 or more occasions using cannabis'. For comparison with much of the existing literature, we dichotomise the resulting data into binary indicators where 0 denotes 'none/not at all' and 1 denotes at least some smoking tobacco, consumption of alcohol, or use of cannabis. By summing across the school class (other than the individual concerned) we construct variables for the prevalence of these behaviours in the class defined as the proportions of the class that have smoked, drank alcohol or used cannabis in the last 30 days (see Table 2). Note that alcohol use is very much a mainstream behaviour for this age group, whereas tobacco and cannabis use are minority behaviours, albeit substantial minorities in each case.

\footnotetext{
${ }^{6}$ These particular data have not previously been used to study peer effects in adolescent substance use. Miller and Plant (2003) do so using an earlier (1999) ESPAD survey, however, treating friends as the relevant reference group and using data on perceived substance use. We do not report the resulting estimates in Table 1, however, because they provide only single equation estimates (treating peer behaviours as if they were exogenous) and their results are not reported in the form of impacts on participation probabilities, and so are not readily comparable with the other Table 1 estimates. Nevertheless, they show strong, positive associations between own substance use and perceived substance use among friends for tobacco, alcohol and cannabis use. McVicar (2011) uses a more recent (2007) ESPAD survey, providing estimates across 26 European countries including the UK (see Table 1).
} 
Crucially for our purposes the questionnaire also asks each individual to report information relating to the behaviour of their friends as well as themselves. In other words we can separately identify the behaviour of each individual's friends from that of each individual's class. Note that because the survey is entirely anonymous we cannot identify who in the class is regarded by who as a friend, or even whether an individual's friends are in or outside his or her class at school. This also means we have no information on the characteristics of friends. The friends' behaviour questions take the following form:

- How many of your friends would you estimate...

o Smoke cigarettes?

o Drink alcoholic beverages (beer, wine, spirits)?

o Smoke cannabis (dope, grass, pot, marijuana) or hashish?

Responses are given on a five point scale labelled 'none’, 'a few', 'some’, 'most', and 'all'. In what follows we use both the raw five-point scale to measure friends' behaviours as well as simple dichotomous indicators for having any friends that smoke or use cannabis or having at least some friends that drink. ${ }^{7}$ Table 2 shows the sample means for these five-point scales.

Note that the questions about own substance use refer to the last 30 days whereas those on perceived friends' substance use do not specify a time period. We proceed on the assumption that this distinction is not critical - both questions can be interpreted as referring to 'current' use. A more important distinction, however, is that our substance-use measure for classmates is expressed as a (quasi-)continuous proportion whereas our perceived substance use measure for

\footnotetext{
${ }^{7}$ The dichotomization for friends' alcohol use differs from that for friends' tobacco and cannabis use because only two percent of the sample report having no friends that drink. Using the same dichotomization (no friends that drink versus at least a few friends that drink) yields similar results to those presented in Table 3 - positive and statistically significant associations between own and friends' drinking - but with a standard error on peer drinking more than double that in Table 3.
} 
friends is expressed as a proportion on a five-point scale. Although we estimate models including behaviours for both reference groups in these different forms, to facilitate comparisons between them we construct similar five-point scale measures for the proportions of classmates engaged in each behaviour. To do so we take the distributions of individuals across the whole sample in each of the five 'friend-use' categories and apply these shares to split the quasi-continuous classmate proportions into five similarly-distributed categories. Table 2 shows means and standard deviations for these constructed scales are very close to those for friends. As we might expect, given that some friends are likely to come from within the school class, these variables are positively correlated, with $\rho=.19$ (drinking), $\rho=.14$ (smoking) and $\rho=.13$ (cannabis use). ${ }^{8}$

Individuals also report on a wide range of questions about their own characteristics, attitudes and family backgrounds. From these we select a small number of individual characteristics and family background controls which will plausibly impact on own substance abuse behaviour: gender; a binary dummy for whether the individual has one or more older siblings engaging in the relevant behaviour; a binary dummy for father with higher education; a binary dummy for describing yourself as ‘academically able’ derived from a seven-point scale asking 'how good you think you are at schoolwork compared to other people your age’ (1= excellent, well above average, above average, 0 otherwise); a binary dummy for living in a two-parent household (including step-parents); and a variable for 'money usually spent in a week for personal needs without parental control' denoted in £s. Our priors for these control variables are uncontroversial: we expect those with higher-educated fathers, those living in two-parent households, those with higher academic ability, and those with less disposable income to engage

\footnotetext{
${ }^{8}$ As an alternative, to test robustness, we recast the five-point scales for friends' substance use as $0, .25, .5, .75$ and 1 and retain the quasi-continuous proportion variables for classmates.
} 
in less substance use (see, e.g. Gaviria and Raphael, 2001; Griesbach et al., 2003; Loureiro et al., 2010).

\section{Approach to Estimation}

This paper extends the approach of Gaviria and Raphael (2001), Powell et al. (2005) and others by including both reference groups in a simple reduced-form regression for substance-use behaviour as given below:

$$
y_{i}^{*}=\alpha+\delta_{1} \bar{y}_{1 i}+\delta_{2} \bar{y}_{2 i}+\beta_{1} X_{1 i}+\beta_{2} X_{2 i}+\ldots+\beta_{k} X_{k i}+u_{i}
$$

where $y_{i}^{*}$ is a latent variable denoting the extent of substance use in the last 30 days for individual $i, \bar{y}_{1 i}$ is the prevalence of substance use among $i$ 's classmates, $\bar{y}_{2 i}$ is the prevalence of (perceived) substance use among i's friends, $X_{1 i}$ to $X_{k i}$ are the set of control variables discussed in the previous section and $u_{i}$ is a normally-distributed error term. Following these earlier studies, (1) makes the assumption that peer characteristics (e.g. their family background) have no direct impact on own behaviour, although they may have an indirect impact via peer substance use. We do not actually observe $y_{i}^{*}$; instead we observe the following dichotomous indicator for substance use:

$$
y_{i}= \begin{cases}0 & \text { if } y_{i}^{*} \leq 0 \\ 1 & \text { if } y_{i}^{*}>0\end{cases}
$$

We therefore estimate (1) and (2) by maximum likelihood as a series of probit models.

We explore a number of different variations of the model above, with each variant intended to be comparable with different subsets of existing estimates in earlier studies. First we assume $\delta_{2}=0$, i.e. that only classmates influence own behaviour, using the continuous measures 
of classmate substance-use prevalence. Results are presented in Table 3 row 1, and essentially they provide UK estimates of peer effects along the lines of the single-equation estimates of Gaviria and Raphael (2001) and Powell et al. (2005) for the US. We then repeat this estimation using an IV probit approach that explicitly treats classmate behaviour as endogenous, with classmate family-background measures instrumenting for classmate substance use along the lines of the IV estimates presented by Gaviria and Raphael (2001) and Powell et al. (2005). Results are presented in row 2 of Table 3. Third, we assume $\delta_{1}=0$, i.e. that only friends influence own behaviour, using simple dichotomous measures of perceived prevalence of substance use amongst friends. Results are presented in Table 3 rows 3 and 5, and essentially provide UK estimates of peer effects along the lines of Norton et al. (2003) and (the naive estimators of) Krauth (2005, 2007). Results where school dummies are included to capture common unobserved influences on substance use are presented in Table 3 rows 4 and $6 .^{9}$

The paper's key results, however, are presented in Table 4. Here the focus is on comparing estimates across reference groups rather than comparing estimates with existing studies, so we replace the continuous and dichotomous reference-group behaviour variables with variables using the common five-point scales. First, we replace the continuous measure of classmate substance use with the constructed five-point scale measure, again assuming $\delta_{2}=0$ (column 1 of Table 4). Second, we similarly replace the dichotomous indicator of friends'

\footnotetext{
${ }^{9}$ Note that the IV approach we use for classmate behaviour is not possible where friends are taken as the reference group because we do not observe any background information for friends. The estimates of peer effects from friends will therefore combine actual peer effects with a mix of biases due to confounding effects, selection, measurement error and systematic misreporting of peer behaviour, for which it is not possible to assign an overall direction. We are therefore reluctant to place a causal interpretation on the estimates using friends. Nevertheless, previous studies provide some reassurance in this respect. Krauth (2005), for example, suggests that selection accounts for around half of the overall association between own smoking and reports of friends' smoking, and if this carried over to our own estimates discussed in the following section then we would still see a large and positive association between own and friends' smoking. Norton et al. (2003) suggests the association between own smoking and perceived friends' smoking is around 1.5 times larger than that between own smoking and actual friends' smoking, and again if this carried over to our own case, and we were interested in actual peer smoking rather than perceived peer smoking, we would still be left with a large and positive peer effect in smoking between friends.
} 
perceived substance use with the five-point scale measure, again assuming $\delta_{1}=0$ (column 2 of Table 4). Finally, we include peer effects from both classmates and friends simultaneously, where substance use behaviours for both reference groups are measured on the five-point scales (column 3 of Table 4). It is this last set of estimates that allows us to distinguish classmate impacts from friend impacts.

We estimate further variants of the model to test the robustness of the key conclusions, including re-estimating with both reference groups included simultaneously using the continuous prevalence measure for classmate behaviour and rescaling the five-point scale for friends as 0/.25/.5/.75/1, re-estimating using binary dummies for the categories on the five-point scales of classmate and friends behaviours in place of the 'raw' five-point scales, and estimating linear versions of all the models. We do not report these results separately given their similarity with the results we do report, although we do refer to them in the discussion where appropriate.

\section{Results and Discussion}

Before discussing our peer effects estimates it is worth briefly considering the estimated impacts on substance use of the control variables. These are robust across the various versions of the model and take expected signs. Adolescents with an older sibling that smokes, drinks or uses cannabis are more likely to do so themselves (e.g. Fletcher, 2010). Girls are more likely than boys to use tobacco (e.g. Loureiro et al., 2010) but less likely than boys to use cannabis (e.g. Miller and Plant, 2003). Father's education level and own academic ability are negatively associated with tobacco and cannabis use (e.g. McVicar, 2011). Living in a two-parent household is negatively associated with tobacco and cannabis use (e.g. Griesbach et al., 2003). Those with more disposable income are more likely to engage in substance use. 
Now turn to the estimated peer effects. First consider the single-equation probit estimates for each of the three behaviours presented in row 1 of Table 3. In each case there is a large, positive and highly statistically significant association between probability of own use and prevalence of use among classmates, with a one percentage point increase in the proportion of the class that drink, smoke, and use cannabis associated with a .59, .37, and .28 percentage point increase, respectively, in probability of own use.

When we instrument for peer behaviour (row 2 of Table 3), the point estimate for alcohol use falls slightly to .55 (but note the weakness of the instruments in this case), whereas the point estimates for tobacco and cannabis use both increase, to .47 and .61 respectively. If anything, IV estimates that are larger than the corresponding single-equation estimates appear to be the norm in this literature: of the six studies listed in Table 1 that present both single equation and IV estimates, four find IV estimates to be larger, one finds no difference, and only one finds IV estimates to be smaller than the corresponding single-equation estimates. Gaviria and Raphael (2001) suggest this may be driven by negative simultaneity bias in the single-equation estimates. But all these estimates are for studies that treat either neighbourhood or school/grade/class as the single reference group, and if behaviour in these reference groups is mostly acting as a proxy for friends' behaviour, attenuation bias due to measurement error may provide an alternative explanation. $^{10}$

Next consider the estimates where friends are taken as the reference group (rows 3-6 of Table 3). Once again, for each behaviour there is a large, positive and highly statistically

\footnotetext{
${ }^{10}$ Micklewright et al. (2010) makes a related point in the context of the peer effects literature on education performance. Their argument is that school-based survey data typically only cover a random sample of peers for each individual, which generates measurement error in peer variables, which in turn can lead to OLS estimates of peer effects being biased towards zero. In an empirical application they show that this bias can be large. Note that the sign of any such bias is less clear in non-linear models such as probits, as are the conditions under which IV provides consistent estimates.
} 
significant association between probability of own use and perceived prevalence of use among friends. Adolescents that report at least some friends that use alcohol are 44 percentage points more likely to drink than those that report none or only a few friends that drink. ${ }^{11}$ Adolescents that report at least a few friends that smoke are 51 percentage points more likely to smoke than those that report no friends that smoke. Adolescents that report at least a few friends that use cannabis are 35 percentage points more likely to use cannabis than those that report no friends that use cannabis. For alcohol and tobacco use, including school dummies reduces the magnitude of the estimated associations, suggesting an additional level of control for school-level confounding factors that otherwise positively bias peer effect estimates, e.g. the existence of a shop close to the school that sells alcohol or cigarettes to adolescents.

Now consider the estimates presented in Table 4. For simplicity we treat the five-point scales as if they were cardinal, which assumes the impact on own substance use of moving from 'a few' to 'some' classmates or friends using the substance is the same as the impact of moving from 'some' to 'most'. All the conclusions hold, however, where we replace the five-point scales with dummies for individual points on each scale, and our focus is on the sign, significance, stability and relative magnitudes of the estimates rather than their absolute magnitudes. Because we cannot instrument for friends' behaviours following the usual method, and because we cannot include school dummies where the class is included as a reference group, we only report singleequation probit estimates. As a consequence, biases of uncertain sign are likely to remain in the Table 4 estimates. Even so, a clear picture emerges of the relative influences of the two reference groups that is unlikely to be driven by biases alone.

\footnotetext{
${ }^{11}$ Adolescents that report at least a few friends that drink (98\% of the sample) are 30 percentage points more likely to drink than those that report no friends that drink.
} 
The first column of Table 4 presents estimated peer effects where the class is taken as the only reference group. Again we see a large, positive and highly statistically significant association between classmates’ drinking and own probability of drinking, with a 'one category' move up the scale associated with a 6.4 percentage point increase in probability of own drinking. The estimates for tobacco and cannabis use are smaller in magnitude - a ‘one category’ move up the scale is associated with an increase in probability of own smoking/cannabis use by 4.1 percentage points and 2.4 percentage points respectively - and are only statistically significant at the $90 \%$ level. $^{12}$ The second column of Table 4 presents estimated peer effects where friends are taken as the only reference group. As in Table 3 we see large, positive and statistically significant associations between friends' substance use and probability of own use, for all three behaviours. In each case these estimated peer effects are considerably larger in magnitude than the equivalent estimates treating the school class as the single reference group $(.21, .26$ and .17 respectively). Finally consider the third column of Table 4 which presents estimated peer effects where we include both reference groups simultaneously. In each case the association between classmates' behaviour and own behaviour disappears whereas the association with friends' behaviour barely changes. The implication is that once you control for friends' behaviour, classmates’ behaviour has no additional influence on own behaviour. In other words, classmate behaviour appears to be proxying for friends’ behaviour in models where friends' behaviour is omitted.

Are there plausible alternative explanations - other than that friends are the relevant reference group for these behaviours and classmates are not - for the pattern of results presented in Table 4? Is it possible, for example, that there are no peer effects here at all and that all we are

\footnotetext{
${ }^{12}$ Bear in mind, however, that the equivalent estimates in Table 3 were shown to be possibly downwards biased, with IV estimates larger in magnitude.
} 
picking up is a positive association between own and friends' reported behaviours due to, say, selection? Evidence from existing studies (e.g. Krauth, 2005), together with the evidence in Table 3 - large and statistically significant IV estimates of peer effects between classmates, and large and statistically significant fixed effects estimates of peer effects between friends suggests that at least some part of these positive associations can be interpreted as causal. So although part of the marginal effect on friends' substance use in each case may be picking up positive biases, it is unlikely that all of the marginal effect in each case is driven by positive biases. It also seems unlikely that the inclusion of the friends' behaviour variables biases all classmates' behaviour coefficients to zero, e.g. given that the control variables generally retain their magnitude and statistical significance.

More likely is that we introduce measurement error when using the constructed five-point scales for classmates' substance use, which could bias the marginal effects towards zero. But this bias would be present whether friends' substance use behaviour was included in the model or not, so is unlikely to explain the contrast between estimated peer effects between classmates when friends' behaviours are included in the models and when they are omitted. To check robustness to this we re-estimate the models where both friends and classmates are included simultaneously as reference groups, but with prevalence of substance use among classmates captured by the original continuous proportion measures. For all three behaviours, the marginal effects on friends' use are again unchanged from those presented in Table 4. There is some muddying of the waters, however, in terms of classmates' impacts, which leads us to tone down our earlier conclusion to some extent. For cannabis use, we once again obtain a zero marginal effect. For tobacco use, we obtain a positive marginal effect that is statistically significant only at the $90 \%$ level, and around half the magnitude of the equivalent marginal effect in Table 3 . For 
alcohol use, we obtain a positive and clearly statistically significant association between classmates' drinking on own drinking, although also around half the magnitude of the equivalent marginal effect in Table 3. So, at least for alcohol and tobacco use, it seems we cannot entirely rule out that classmates have an impact over and above that of friends, although we show that this impact is much reduced in magnitude by the inclusion of friends' behaviours in the model.

\section{Conclusions}

This paper estimates peer influences on the alcohol, tobacco and cannabis use of a sample of UK 15 year olds, contributing new estimates to a literature predominantly using US data. As is the case for many existing studies of peer effects in adolescent substance use, we provide estimates of peer effects where the school class is taken as the relevant reference group. Our findings suggest the existence of large, positive and highly statistically significant peer effects in all three behaviours, whether peer behaviour is instrumented or not. Further, although we don't observe friendship links explicitly in the data, we are able to use information on friends' perceived behaviours as reported by each individual to estimate peer effects between friends. Again the resulting estimates suggest large, positive and highly statistically significant associations between own substance use and friends’ perceived substance use in all three behaviours.

The main contribution of the paper, however, is to show that the influence of classmates is much diminished, and may even disappear altogether, where both reference groups (friends and classmates) are included in a regression for own behaviour. In other words friends are the more relevant reference group for peer effects in adolescent substance use, and classmates that are not friends may have little or no additional influence, at least in these data. Such evidence is critical to understanding adolescent substance use. It can help guide future studies of adolescent 
substance use, and studies of peer effects in particular, towards arguably more appropriate models and data sources. It can also help us interpret the range of existing estimates in the adolescent substance use peer effects literature. A finding of zero peer effects between classmates, where only classmates are included as a reference group, does not imply zero peer effects between friends or other possible reference groups. Further, policy interventions that aim to exploit social multipliers to reduce adolescent substance use may be more successful at the friendship cluster level rather than school/grade/class level. 


\section{References}

Brock, W. and Durlauf, S. (2001). 'Interaction-based models', in J. Heckman and E. Leamer (eds.), Handbook of Econometrics, vol. 5, Amsterdam: North-Holland.

Calvo-Arnengol, A., Pattachnini, E. and Zenou, Y. (2009). 'Peer effects and social networks in education', Review of Economic Studies, Vol. 76, pp. 1239-1267.

Case, A.C. and Katz, L.F. (1991). 'The company you keep: the effects of family and neighbourhood on disadvantaged youths’, NBER working Paper No. 3705, Cambridge MA.

Clark, A.E. and Lohéac, Y. (2007). 'It wasn't me, it was them! Social influence in risky behaviour of adolescents', Journal of Health Economics, Vol. 26, pp. 763-784.

Eisenberg, D. (2004).’Peer effects for adolescent substance use: do they really exist?' Working Paper UC-Berkeley School of Public Health.

Gaviria, A. and Raphael, S. (2001). 'School-based peer effects and juvenile behaviour', Review of Economics and Statistics, Vol. 83, pp. 257-268.

Granovetter, M. (1973). 'The strength of weak ties’, American Journal of Sociology, Vol. 78, pp. 1360-1380.

Griesbach, D., Amos, A., and Currie, C. (2003). 'Adolescent smoking and family structure in Europe’, Social Science and Medicine, Vol. 56, pp. 41-52.

Ioannides, Y. (2008). 'Social interactions (empirics),' in S. Durlauf and L. Blume (eds.), New Palgrave Dictionary of Economics $2^{\text {nd }}$ Edition, Palgrave Macmillan.

Jackson, M.O. and Wolinsky, A. (1996). 'A strategic model of social and economic networks’, Journal of Economic Theory, Vol. 71, pp. 44-74. 
Kawaguchi, D. (2004). 'Peer effects on substance use among American teenagers', Journal of Population Economics, Vol. 17, pp. 351-367.

Krauth, B.V. (2005). 'Peer effects and selection effects on smoking among Canadian youth', Canadian Journal of Economics, Vol. 38, pp. 735-756.

Krauth, B.V. (2007). 'Peer and selection effects on youth smoking in California', Journal of Business and Economic Statistics, Vol. 25, pp. 288-298.

Loureiro, M.L., Sanz-de-Galdeano, A. and Vuri, D. (2010). 'Smoking habits: like father, like son, like mother, like daughter?' Oxford Bulletin of Economics and Statistics, Vol. 72, pp. 717743.

Lundborg, P. (2006). 'Having the wrong friends? Peer effects in adolescent substance use', Journal of Health Economics, Vol. 25: pp. 214-233.

Manski, C. (1993). 'Identification of endogenous social effects: the reflection problem', Review of Economic Studies, Vol. 60, pp. 531-542.

McVicar, D. (2011). 'Estimates of peer effects in adolescent smoking across twenty six European countries', Social Science \& Medicine, Vol. 73, pp.1186-1193.

Micklewright, J., Schnepf, S.V. and Silva, P.N. (2010). 'Peer effects and measurement error: the impact of sampling variation in school survey data', Mimeo, Institute of Education, University of London.

Miller, P. and Plant, M. (2003). 'The family, peer influences and substance use: findings from a study of UK teenagers', Journal of Substance Use, Vol. 8, pp. 19-26. 
Norton, E.C., Lindrooth, R.C. and Ennett, S.T. (2003). How measures of perception from survey data lead to inconsistent regression results: evidence from adolescent and peer substance use', Health Economics, Vol. 12, pp. 139-148.

Oetting, E. R., and Beauvais, F. (1987). Peer cluster theory, socialization characteristics, and adolescent drug use: A path analysis', Journal of Counseling Psychology, Vol. 34, pp. 205-213.

Powell, L.M., John, A. and Hana, R. (2005). 'The importance of peer effects, cigarette prices and tobacco control policies for youth smoking behaviour', Journal of Health Economics, Vol. 24, pp. 950-968.

Sen, A. (2009). 'Estimating the impacts of household behaviour on youth smoking: evidence from Ontario, Canada', Review of Economics of the Household, Vol. 7, pp. 189-218.

Soetevent, A.R. (2006). 'Empirics of the identification of social interactions: an evaluation of the approaches and their results’, Journal of Economic Surveys, Vol. 20, pp. 193-228.

Soetevent, A.R. and Kooreman, P. (2007). 'A discrete choice model with social interactions: an application to high school teen behaviour', Journal of Applied Econometrics Vol. 22, pp. 599624. 
TABLE 1

Peer Effects in Adolescent Substance Use, Existing Studies

\begin{tabular}{|c|c|c|c|c|c|}
\hline Study & Data & Behaviour & $\begin{array}{l}\text { Reference } \\
\text { Group(s) }\end{array}$ & Methods & Key estimates \\
\hline $\begin{array}{l}\text { Case \& } \\
\text { Katz } \\
(1991) \\
\end{array}$ & $\begin{array}{l}\text { Boston Youth Survey } \\
\text { (household survey, } \\
\text { US, } n \approx 1,000 \text { ) }\end{array}$ & $\begin{array}{l}\text { Illegal drug } \\
\text { use }\end{array}$ & $\begin{array}{l}\text { Neighbourhood } \\
\text { (city block) }\end{array}$ & $\begin{array}{l}\text { Probit } \\
\text { IV }\end{array}$ & $\begin{array}{l}.320^{* * * *} \\
.383^{* * *}\end{array}$ \\
\hline $\begin{array}{l}\text { Gaviria \& } \\
\text { Raphael } \\
\text { (2001) }\end{array}$ & $\begin{array}{l}\text { National Educational } \\
\text { Longitudinal Survey } \\
\text { (school-based survey, } \\
\text { US, } n \approx 12,300 \text { ) }\end{array}$ & $\begin{array}{l}\text { Drug use, } \\
\text { drinking, } \\
\text { tobacco } \\
\text { smoking }\end{array}$ & School & OLS & $\begin{array}{l}.254^{* * *}, .186^{* * *}, .158^{* * *} \\
.322^{* * *}, .354^{* * *}, .156\end{array}$ \\
\hline \multirow[t]{2}{*}{$\begin{array}{l}\text { Norton et } \\
\text { al. (2003) }\end{array}$} & $\begin{array}{l}\text { North Carolina } \\
\text { smoking study } \\
\text { (school-based survey, } \\
\text { US, } n \approx 800 \text { ) }\end{array}$ & $\begin{array}{l}\text { Tobacco } \\
\text { smoking }\end{array}$ & $\begin{array}{l}\text { Closest friends } \\
\text { within school } \\
\text { (actual and } \\
\text { perceived use) }\end{array}$ & $\begin{array}{l}\text { OLS actual } \\
\text { (perceived) }\end{array}$ & $.526^{* * *}\left(.767^{* * *}\right)$ \\
\hline & $\begin{array}{l}\text { Illinois } \\
\text { smoking/drinking } \\
\text { study (school-based } \\
\text { survey, US, } \mathrm{n} \approx 1,600 \text { ) } \\
\end{array}$ & $\begin{array}{l}\text { Tobacco } \\
\text { smoking, } \\
\text { drinking }\end{array}$ & $\begin{array}{l}\text { Friends within } \\
\text { school (actual } \\
\text { and perceived } \\
\text { use) }\end{array}$ & $\begin{array}{l}\text { OLS actual } \\
\text { (perceived) }\end{array}$ & $\begin{array}{l}.397^{* * *}\left(.220^{* * *}\right), \\
.329^{* *}\left(.343^{* * *}\right)\end{array}$ \\
\hline \multirow[t]{2}{*}{$\begin{array}{l}\text { Kawaguchi } \\
\text { (2004) }\end{array}$} & \multirow[t]{2}{*}{$\begin{array}{l}\text { National Longitudinal } \\
\text { Survey of Youth } \\
\text { (youth survey, US, } \\
\mathrm{n} \approx 2,500-6,300 \text { ) }\end{array}$} & \multirow[t]{2}{*}{$\begin{array}{l}\text { Tobacco } \\
\text { smoking, } \\
\text { drinking, } \\
\text { cannabis use }\end{array}$} & \multirow[t]{2}{*}{$\begin{array}{l}\text { Friends } \\
\text { (perceived use) }\end{array}$} & $\begin{array}{l}\text { Probit } \\
\text { School } \\
\text { random } \\
\text { effects }\end{array}$ & $\begin{array}{l}.205^{* * *}, .263^{* * *}, .141^{* * *} \\
.205^{* * *}, .258^{* * *}, 138^{* * *}\end{array}$ \\
\hline & & & & $\begin{array}{l}\text { Sibling fixed } \\
\text { effects }\end{array}$ & $.077^{* * *}, .169^{* * *}, .031^{* * *}$ \\
\hline \multirow[t]{2}{*}{$\begin{array}{l}\text { Eisenberg } \\
\text { (2004) }\end{array}$} & $\begin{array}{l}\text { Add Health (school- } \\
\text { based survey, US, } \\
\text { includes friendship } \\
\text { network data, } \\
\mathrm{n} \approx 1,500 \text { ) }\end{array}$ & \multirow[t]{2}{*}{$\begin{array}{l}\text { Tobacco } \\
\text { smoking, } \\
\text { drinking, } \\
\text { binge } \\
\text { drinking, } \\
\text { cannabis use }\end{array}$} & $\begin{array}{l}\text { Closest friends } \\
\text { within school }\end{array}$ & $\begin{array}{l}\text { Probit: } \\
\text { removal of } \\
\text { user friend; } \\
\text { (friend } \\
\text { graduates) }\end{array}$ & $\begin{array}{l}-.033, .083, .059^{*}, .117^{* *} \\
\left(.048^{* *}, .045, .052^{* * *},\right. \\
-.014)\end{array}$ \\
\hline & $\begin{array}{l}\text { National } \\
\text { Educational } \\
\text { Longitudinal Survey } \\
\text { (school-based survey, } \\
\text { US, } n \approx 2,300-19,300 \text { ) }\end{array}$ & & $\begin{array}{l}\text { Presence of } \\
\text { older school } \\
\text { grades as proxy } \\
\text { for school-level } \\
\text { behaviour }\end{array}$ & Probit $^{\wedge}$ & $.009^{*},-.016, .009,-.040^{* * *}$ \\
\hline $\begin{array}{l}\text { Powell et } \\
\text { al. (2005) }\end{array}$ & $\begin{array}{l}\text { Study of Smoking } \\
\text { and Tobacco Use } \\
\text { Among Young People } \\
\text { (school-based survey, } \\
\text { US, } n \approx 12,700 \text { ) }\end{array}$ & $\begin{array}{l}\text { Tobacco } \\
\text { smoking }\end{array}$ & School & $\begin{array}{l}\text { Probit } \\
\text { IV }\end{array}$ & $\begin{array}{l}.578^{* * *} \\
.576^{* * *}\end{array}$ \\
\hline $\begin{array}{l}\text { Krauth } \\
\text { (2005) }\end{array}$ & $\begin{array}{l}\text { Youth Smoking } \\
\text { Survey (household } \\
\text { survey, Canada, } \\
n \approx 9,000 \text { ) }\end{array}$ & $\begin{array}{l}\text { Tobacco } \\
\text { smoking }\end{array}$ & $\begin{array}{l}\text { Friends } \\
\text { (perceived use) }\end{array}$ & $\begin{array}{l}\text { Probit } \\
\text { With } \\
\text { selection }\end{array}$ & $\begin{array}{l}.681^{* * *} \\
.267^{* * *}\end{array}$ \\
\hline $\begin{array}{l}\text { Lundborg } \\
\text { (2006) }\end{array}$ & $\begin{array}{l}\text { Trelleborg schools } \\
\text { survey (school-based } \\
\text { survey, Sweden, } \\
\mathrm{n} \approx 2,500 \text { ) }\end{array}$ & $\begin{array}{l}\text { Binge } \\
\text { drinking, } \\
\text { tobacco } \\
\text { smoking, }\end{array}$ & School class & $\begin{array}{l}\text { Probit } \\
\text { School FE }\end{array}$ & $\begin{array}{l}.284^{* * *}, .180^{* * *}, .057^{* * *} \\
.230^{* * *}, .166^{* * *}, .065^{* * *}\end{array}$ \\
\hline
\end{tabular}




\begin{tabular}{|c|c|c|c|c|c|}
\hline & & $\begin{array}{l}\text { illicit drug } \\
\text { use }\end{array}$ & & $\begin{array}{l}\text { IV \& school } \\
\text { FE }\end{array}$ & $.557^{* * *}, .470^{* * *}, .159^{* *}$ \\
\hline \multirow{2}{*}{$\begin{array}{l}\text { Krauth } \\
(2007)\end{array}$} & California Youth & $\begin{array}{l}\text { Tobacco } \\
\text { smoking }\end{array}$ & $\begin{array}{l}\text { Friends (same } \\
\text { sex, perceived }\end{array}$ & Probit & $.427^{* * * *}$ \\
\hline & $\begin{array}{l}\text { (household survey, } \\
\text { US, } n \approx 13,000 \text { ) }\end{array}$ & & use) & $\begin{array}{l}\text { With } \\
\text { selection }\end{array}$ & .040 \\
\hline \multirow{2}{*}{$\begin{array}{l}\text { Soetevent } \\
\& \\
\text { Kooreman } \\
(2007)^{\wedge}\end{array}$} & \multirow{2}{*}{$\begin{array}{l}\text { National School } \\
\text { Youth Survey } \\
\text { (school-based survey, } \\
\text { Netherlands, } n \approx 7,500 \text { ) }\end{array}$} & \multirow[t]{2}{*}{$\begin{array}{l}\text { Tobacco } \\
\text { smoking }\end{array}$} & \multirow[t]{2}{*}{$\begin{array}{l}\text { School class } \\
\text { (same sex } \\
\text { classmates) }\end{array}$} & $\begin{array}{l}\text { Probit, boys } \\
\text { (girls) }\end{array}$ & $.722^{* * *}\left(.575^{* * *}\right)$ \\
\hline & & & & $\begin{array}{l}\text { School FE, } \\
\text { boys (girls) }\end{array}$ & $.125(.113)$ \\
\hline \multirow[t]{3}{*}{$\begin{array}{l}\text { Clark and } \\
\text { Lohéac } \\
\text { (2007) }\end{array}$} & \multirow[t]{3}{*}{$\begin{array}{l}\text { Add Health (school- } \\
\text { based survey, US, } \\
\text { includes friendship } \\
\text { network data, } \\
\mathrm{n} \approx 9,600 \text { ) }\end{array}$} & \multirow[t]{3}{*}{$\begin{array}{l}\text { Tobacco } \\
\text { use, } \\
\text { drinking, } \\
\text { drunkenness, } \\
\text { cannabis use }\end{array}$} & \multirow[t]{2}{*}{ School grade } & $\begin{array}{l}\text { Lagged peer } \\
\text { behaviour, } \\
\text { boys (girls) }\end{array}$ & $\begin{array}{l}.220^{* * *}\left(.182^{* * *}\right), \\
.248^{* * *}\left(.141^{* * *}\right), \\
.259^{* * *}\left(.131^{* * *}\right), \\
.255^{* * *}\left(.174^{* * *}\right)\end{array}$ \\
\hline & & & & $\begin{array}{l}\text { Lagged peer } \\
\text { behaviour \& } \\
\text { school FE, } \\
\text { boys (girls) }\end{array}$ & $\begin{array}{l}.088^{*}(-.024), \\
.181^{* * * *}(.052), \\
.170^{* * *}(.048), \\
.055(-.033)\end{array}$ \\
\hline & & & $\begin{array}{l}\text { Closest friends } \\
\text { within school }\end{array}$ & $\begin{array}{l}\text { Lagged peer } \\
\text { behaviour \& } \\
\text { school FE, } \\
\text { boys (girls) } \\
\end{array}$ & $\begin{array}{l}.185^{* * *}\left(.208^{* * *}\right), \\
.118^{* * *}\left(.127^{* * *}\right), \\
.131^{* * *}\left(.125^{* * *}\right), \\
.123^{* * *}\left(.105^{* * *}\right)\end{array}$ \\
\hline \multirow[t]{4}{*}{ Sen (2009) } & \multirow{4}{*}{$\begin{array}{l}\text { Waterloo Smoking } \\
\text { prevention Program } \\
\text { (school-based survey, } \\
\text { Canada, } n \approx 6,000 \text { ) }\end{array}$} & \multirow[t]{4}{*}{$\begin{array}{l}\text { Tobacco } \\
\text { smoking }\end{array}$} & \multirow[t]{4}{*}{ School class } & $\begin{array}{l}\text { OLS, boys } \\
\text { (girls) }\end{array}$ & $.812^{* * *}\left(.733^{* * *}\right)$ \\
\hline & & & & $\begin{array}{l}\text { School FE, } \\
\text { boys (girls) }\end{array}$ & $.835^{* * *}\left(.769^{* * *}\right)$ \\
\hline & & & & $\begin{array}{l}\text { School \& } \\
\text { individual } \\
\text { FE, boys } \\
\text { (girls) }\end{array}$ & $.387^{* *}\left(.298^{* * *}\right)$ \\
\hline & & & & $\begin{array}{l}\text { IV \& school } \\
\text { FE, boys } \\
\text { (girls) }\end{array}$ & $.567^{* * *}\left(.539^{* * *}\right)$ \\
\hline \multirow[t]{2}{*}{$\begin{array}{l}\text { Fletcher } \\
\text { (2010) }\end{array}$} & \multirow{2}{*}{$\begin{array}{l}\text { Add Health (school- } \\
\text { based survey, US, } \\
\text { includes friendship } \\
\text { network data, } \\
\mathrm{n} \approx 13,000 \text { ) }\end{array}$} & \multirow[t]{2}{*}{$\begin{array}{l}\text { Tobacco } \\
\text { smoking }\end{array}$} & \multirow[t]{2}{*}{ School grade } & IV & $.393^{* * *}$ \\
\hline & & & & $\begin{array}{l}\text { IV \& school } \\
\text { FE }\end{array}$ & $.345^{* * *}$ \\
\hline \multirow[t]{2}{*}{$\begin{array}{l}\text { McVicar } \\
\text { (2011) }\end{array}$} & $\begin{array}{l}\text { ESPAD } 2007 \text { (school- } \\
\text { based survey across }\end{array}$ & \multirow[t]{2}{*}{$\begin{array}{l}\text { Tobacco } \\
\text { smoking }\end{array}$} & \multirow[t]{2}{*}{ School class } & Probit & \\
\hline & $\begin{array}{l}26 \text { European } \\
\text { countries, } \mathrm{n} \approx 77,000 \text { ) }\end{array}$ & & & IV & $.382^{* * *}$ \\
\hline
\end{tabular}

Notes: Key estimates are for boys and girls jointly unless otherwise stated, and are reported as either coefficients (OLS) or marginal effects (probit) - interpretable as the percentage point increase in the probability of the individual smoking/drinking/using cannabis associated with a one percentage point increase in the proportion of the reference group smoking/drinking/using cannabis - again unless otherwise stated. ***, ** and * denote statistical significance at $99 \%, 95 \%$ and $90 \%$ levels respectively. IV = instrumental variables, $\mathrm{FE}=$ fixed effects. ${ }^{\wedge}$ These estimates show the impact on own behaviour of being in a school with older grades for $8^{\text {th }}$ graders. ${ }^{\wedge}$ Soetevent $\&$ Kooreman (2007) also report inter-gender peer effects, which are generally smaller than their intra-gender peer effects estimates. 
TABLE 2

Descriptive Statistics on Adolescent Substance Use, Alternative Measures

\begin{tabular}{lccc}
\hline \multicolumn{1}{c}{ Measure } & \multicolumn{3}{c}{ Sample Mean (Standard Deviation) } \\
& Alcohol & Tobacco & Cannabis \\
\hline Own use scale 1-7 & 2.79 & 1.88 & 1.48 \\
& $(1.55)$ & $(1.55)$ & $(1.22)$ \\
Individual has used substance in last 30 days & .750 & .297 & .199 \\
Proportion of class using substance in last 30 & .750 & .297 & .199 \\
days & & & \\
Proportion of class using substance in last 30 & 3.92 & 2.94 & 2.38 \\
days: constructed 5-point scale & $(.889)$ & $(.959)$ & $(1.07)$ \\
Proportion of friends using substance: 5-point & 3.93 & 2.94 & 2.40 \\
scale & $(.885)$ & $(.954)$ & $(1.07)$ \\
\hline
\end{tabular}

Notes: The 5-point scale for proportion of friends/classmates using the substance are defined as $1=$ none, $2=a$ few, 3=some, $4=$ most and 5=all (see Section 3). Nobs=1791. 
TABLE 3

Peer Effects in Alcohol, Tobacco and Cannabis Use, Alternative Reference Groups, Marginal Effects (Standard Errors)

\begin{tabular}{lccc}
\hline & Alcohol & Tobacco & Cannabis \\
\hline Probit, proportion of class using substance in last 30 & $.593^{* * *}$ & $.365^{* * *}$ & $.279^{* *}$ \\
days (\%) & $(.072)$ & $(.121)$ & $(.116)$ \\
IV, proportion of class using substance in last 30 & $.554^{*}$ & $.466^{* * *}$ & $.606^{* * *}$ \\
days (\%) & $(.291)$ & $(.133)$ & $(.136)$ \\
Probit, at least some friends used alcohol in last 30 & $.437^{* * *}$ & & \\
days & $(.044)$ & & \\
Probit, at least some friends used alcohol in last 30 & $.355^{* * *}$ & & \\
days, with school fixed effects & $(.046)$ & $.506^{* * *}$ & $.350^{* * *}$ \\
Probit, at least a few friends used tobacco/cannabis & & $(.098)$ & $(.043)$ \\
in last 30 days & & $.474^{* * *}$ & $.332^{* * *}$ \\
Probit, at least a few friends used tobacco/cannabis & & $(.091)$ & $(.044)$ \\
in last 30 days, with school fixed effects & & & \\
\hline
\end{tabular}

Notes: $* * *, * *$ and $*$ denote statistical significance at $99 \%, 95 \%$ and $90 \%$ levels. The dependent variable is whether you drank alcohol, smoked tobacco or used cannabis in the last 30 days. Errors are clustered at classroom level. Marginal effects are calculated at means. For the peer behaviour variables they indicate either the difference in the probability of own substance use between an individual in a class where no classmates drink/smoke/use cannabis and a class where all classmates do so, the difference in the probability of own drinking between an individual with at least some friends that drink relative to an individual with no or only a few friends that do so, or between an individual with at least a few friends that smoke/use cannabis relative to an individual with no friends that smoke/use cannabis. The following controls are included in each case: sex, older sibling substance use, father's qualification level, self-reported academic ability, a dummy for living in a two parent household, and the amount of own money to spend without supervision each week. The IV probits use the following instruments for peer behaviour: alcohol (class proportion with older sibling drinking, class mean money per week); tobacco (class proportion with older sibling smoking, class share with higher educated father, class share describing themselves as academically able, class share living in two parent households); cannabis (class proportion with older sibling using cannabis, class share with higher educated father). F-stats for first stage relevance of excluded instruments are 3.7, 20.6 and 14.5 respectively for the three models. Chi-square tests for instrument excludability suggest we cannot rule out valid excludability in each case (p-values are $.97, .44$ and .17 respectively). The probits with school fixed effects exclude schools where all or no individuals drink/smoke/use cannabis (nobs range from 1742 to 1791). Pseudo $\mathrm{R}^{2} \mathrm{~s}$ range between .068 and .188. 
TABLE 4

Peer Effects in Alcohol, Tobacco and Cannabis Use, Combined Reference Groups \& Five Point Scales, Marginal Effects (Standard Errors)

\begin{tabular}{|c|c|c|c|}
\hline & $\begin{array}{l}\text { Model } 1 \text { (class as ref } \\
\text { group) }\end{array}$ & $\begin{array}{l}\text { Model } 2 \text { (friends as } \\
\text { ref group) }\end{array}$ & $\begin{array}{l}\text { Model } 3 \text { (both ref } \\
\text { groups) }\end{array}$ \\
\hline \multicolumn{4}{|l|}{ Alcohol } \\
\hline $\begin{array}{l}\text { Proportion in class that drink (constructed } 5 \\
\text { point scale) }\end{array}$ & $\begin{array}{c}.064 * * * \\
(.021)\end{array}$ & & $\begin{array}{c}.026 \\
(.020)\end{array}$ \\
\hline Proportion of friends that drink (5 point scale) & & $\begin{array}{c}.209 * * * \\
(.016)\end{array}$ & $\begin{array}{c}.204 * * * \\
(.016)\end{array}$ \\
\hline Pseudo $\mathrm{R}^{2}$ & .056 & .177 & .179 \\
\hline \multicolumn{4}{|l|}{ Tobacco } \\
\hline $\begin{array}{l}\text { Proportion in class that smoke (constructed } 5 \\
\text { point scale) }\end{array}$ & $\begin{array}{l}.041^{*} \\
(.023)\end{array}$ & & $\begin{array}{c}.020 \\
(.021)\end{array}$ \\
\hline $\begin{array}{l}\text { Proportion of friends that smoke ( } 5 \text { point } \\
\text { scale) }\end{array}$ & & $\begin{array}{c}.257^{* * *} \\
(.018)\end{array}$ & $\begin{array}{c}.253^{* * *} \\
(.018)\end{array}$ \\
\hline Pseudo $\mathrm{R}^{2}$ & .110 & .240 & .241 \\
\hline \multicolumn{4}{|l|}{ Cannabis } \\
\hline $\begin{array}{l}\text { Proportion in class that use cannabis } \\
\text { (constructed } 5 \text { point scale) }\end{array}$ & $\begin{array}{l}.024^{*} \\
(.014)\end{array}$ & & $\begin{array}{c}.006 \\
(.013)\end{array}$ \\
\hline $\begin{array}{l}\text { Proportion of friends that use cannabis ( } 5 \\
\text { point scale) }\end{array}$ & & $\begin{array}{c}.170^{* * *} \\
(.015)\end{array}$ & $\begin{array}{c}.169 * * * \\
(.016)\end{array}$ \\
\hline Pseudo $\mathrm{R}^{2}$ & .085 & .273 & .274 \\
\hline
\end{tabular}

Notes: ***, ** and $*$ denote statistical significance at $99 \%, 95 \%$ and $90 \%$ levels. The dependent variable is whether you drank alcohol in the last 30 days. The peer behaviour variables are 5 point scales in each case: as recorded in the data for friends and as constructed from class proportions for classmates ( $1=$ none, $2=\mathrm{a}$ few, $3=$ some, $4=$ most, $5=$ all). Errors are clustered at classroom level. Marginal effects are calculated at sample means. For the peer behaviour variables they indicate the impact on the probability of own substance use of a one unit increase in peer substance use (a one point move up the five point scale). The following controls are included in each case: sex, older sibling substance use, father's qualification level, self-reported academic ability, a dummy for living in a two parent household, and the amount of own money to spend without supervision each week. Nobs=1791. 